(Teknologi Rekayasa Jaringan Telekomunikasi) : Jurnal Teknik Elektro

Volume 1, Nomor 1, April 2021

DOI: https://doi.org/10.51510/trekritel.v1i1.397

\title{
Perancangan Dan Pembuatan Alat Pengontrol Lampu Menggunakan Internet Of Things (IOT) Berbasis Arduino Uno
}

\author{
Henni Meyliana, Nabila Octavia \\ Program Studi Teknik Telekomunikasi \\ Politeknik Negeri Medan \\ Jl. Almamater, No. 1 Medan Telp. (061) 8211235, Kode Pos 20155, Indonesia \\ e-mail: hennimeyliana@gmail.com
}

\begin{abstract}
Abstrak - Dalam memanfaatkan untuk penghematan penggunaan listrik yang terbatas bisa dilakukan didalam dan diluar ruangan yang tertentu saja. Seperti hal nya menggunakan listrik untuk menghidupkan lampu didalam ruangan yang gelap, sehingga ruangan tersebut dipantulkan cahaya pada lampu yang sudah dialiri listrik. Penggunaan lampu yang terbatas akan menghemat biaya operasional tagihan kepada pihak PLN. Terlebih daripada itu jaringan listrik sudah diperbaharui menggunakan internet, sehingga masyarakat pengguna listrik dapat lebih mudah dalam melakukan transaksi listrik yang diperlukan. Sehubung dengan munculnya internet sebagai alat informasi dan komunikasi antar manusia telah merubah suasana untuk beraktifitas lebih mudah, bahkan peralatan untuk terkoneksi dengan internet rata-rata sudah tersedia. Internet of Things atau disingkat IoT merupakan sebuah implementasi komunikasi terhadap jaringan dari benda yang saling berhubungan antara satu dengan yang lain dalam berkomunikasi. Terutama internet juga sudah melekat pada Smartphone. Smartphone merupakan sebuah alat perangkat yang mampu dalam mengembangkan Internet of Things (IoT). Smartphone berfungsi untuk mengkoneksikan jaringan internet yang sudah dilengkapi dengan fitur berupa sensor. Dalam menggunakan IoT sebagai alat infrakstruktur jaringan maka akan dapat mengontrol dan memonitoring sebuah alat yang telah ditentukan berupa Arduino Uno. Arduino uno berfungsi sebagai pengembangan mikrokontroler yang telah terhubung dengan internet, sehingga dapat mempermudah dalam penggunaan lampu dikehidupan sehari-hari. Sistem operasi open source pada smartphone android dapat dimanfaatkan sebagai bahan perancangan alat pengontrol lampu yang menggunakan internet of thins (IoT) berbasis arduino uno (mikrokontroler Atmega328) dan relay sebagai pengganti saklar. Maka dari itu, dalam melakukan pengujian alat yang menggunakan arduino yang memiliki penjedaan waktu selama 1 menit. Untuk penggunaan program arduino uno juga diberikan penjedaan waktu selama 5 detik, sambil menunggu perpindahan perintah serial dari satu relay ke relay yang lain.
\end{abstract}

Kata kunci : Lampu, IoT, Arduino Uno, Relay

Abstract - At the utilizing to apply limited electricity usage, it can be done inside and outside certain rooms. Like it uses electricity to turn on the lights in a dark room, so that the room is reflected by the light that has been electrified. The limited use of lights will protect the operational costs of bills from PLN. Especially in the electricity network already using the internet, so that people who use electricity can more easily carry out the electricity transactions needed. In connection with the internet's intelligence as a means of information and communication between humans, it has changed the atmosphere for easier activities, even the equipment to connect to the internet is on average already available. Internet of Things or abbreviated as IoT is an implementation of communication on a network of objects that are interconnected with one another in communication. The internet has also been attached to smartphones. Smartphone is a device capable of developing the Internet of Things (IoT). Smartphones function to connect to an internet network that is equipped with features in the form of sensors. In using IoT as a network infrastructure tool, it will be able to control and monitor a predetermined device in the form of an Arduino Uno. Arduino does not function as a microcontroller development that is connected to the internet, so that it can make it easier to use lights in everyday life. The open source operating system on an Android smartphone can be used as a material for designing a lamp controller using the internet of thins (IoT) based on Arduino Uno (Atmega328 microcontroller) and a relay as a switch. Therefore, in 
testing the tool using Arduino which has a time lag of 1 minute. For the use of the Arduino Uno program, a time delay of 5 seconds is also provided, while waiting for the serial command to move from one relay to another.

Keywords : Lights, IoT, Arduino Uno, Relay

\section{Pendahuluan}

\section{A. Latar Belakang}

Perkembangan tahun ke tahun di dunia semakin membuat jaman teknologi semakin canggih dan kompeten, sehingga dapat bermanfaat yang baik bagi semua orang pengguna teknologi. Teknologi di rancang berbentung peralatan yang berfungsi untuk mempermudah aktifitas manusia dalam menggunakannya, baik itu didalalam ruangan maupun diluar lapangan. Pengendalian teknologi yang baik akan mendapatkan hasil yang bagus. Salah satunya ialah teknologi sebagai alat pengontrol lampu pada ruangan. Penggunaan lampu tersebut sangat penting untuk menerangi sebuah ruangan yang gelap dan tertutup, sehingga lampu merupakan pokok penting bagi penghidupan dan kehidupan manusia sehari-hari. Tetapi, saat pengguna memiliki kesulitan untuk menyalakan dan mematikan lampu tersebut, maka dibutuhkannya suatu alat yang mempermudah dalam beraktifitas yaitu pengontrol lampu pada ruangan.

Dalam melakukan proses sebuah perancangan alat pengontrol lampu pada ruangan, diperlukan kehadiran internet sebagai letak penghubung bahan informasi dan komunikasi antar manusia yang baik. Internet yang diperlukan juga tidak hanya digunakan untuk menghubungkan komunikasi antar manusia, tetapi sudah terhubung secara otomatis ke berbagai bentuk peralatan yang bisa dihubungkan. Seperti hal nya, menggunakan Internet of Things (IoT) yang bertujuan sebagai alat perencanaan komunikasi antar jaringan yang saling terhubung satu dengan yang lain dengan menggunakan smartphone. Smartphone kini sudah banyak bertebaran dilingkungan sekitar, karena masyarakat sangat membutuhkan sebuah alat untuk mempermudah aktifitasnya tersebut. Melalui perancangan ini smartphone juga memiliki kemampuan yang baik untuk mengkoneksikan jaringan internet yang terhubung luas, yang didalamnya dilengkapi alat berupa fitur sensor. Fitur sensor ini yang akan bekerja pada alat pengontrol lampu pada ruangan tersebut.

Dengan demikian dengan menggunakan Internet of Things (IOT) sebagai sarana infrakstruktur jaringan yang menyimpan projek kontrol dan dapat mengamati serta memonitoring sebuah alat dari Arduino Uno, sampai kepada mikrokontroler yang sangat cocok untuk dapat menghubungkan ke jaringan internet. Maka dari itu, diharapkan perancangan alat pengontrol ini dapat mempermudah bagi manusia yang dalam kehidupan seharinya selalu memakai lampu sebagai alat penerangan kehidupan sehari-hari.

\section{STUDI PUSTAKA}

\section{A. Landasan Teori}

Lampu merupakan sebuah alat yang berbentuk botol dan terdapat kawat didalamnya sebagai alat penghubung ke aliran listrik, yang bergungsi untuk menghasilkan penerangan sinar cahaya pada suatu tempat. Seperti hal nya penggunaan lampu berjenis Lampu LED. Lampu LED merupakan jenis lampu yang paling hemat pemakaian energinya dan bentuk konstruksinya kecil dan uniknya memiliki jenis yang bisa digunakan dalam bermacam-macam warna-warni yang indah.

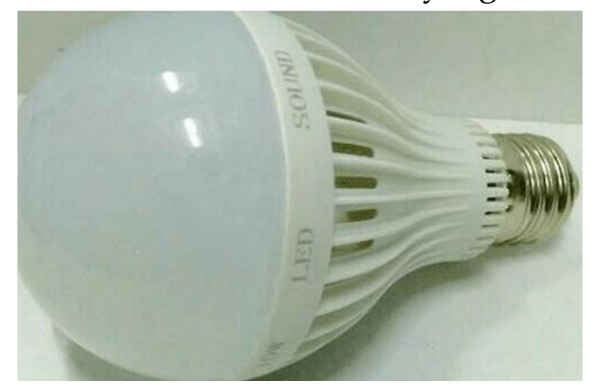

Gambar 1. Lampu LED 
Internet of Things ( IOT ) merupakan bentuk arsitektur sistem yang terdiri dari perangkat keras, perangkat lunak, dan Web. Perbedaan protokol antara perangkat keras dengan protokol web yaitu berupa gateway sebagai alat penghubung dari perbedan protokol tersebut. Lebih dominannya perangkat sudah pasti akan terkoneksi ke internet dengan menggunakan beberapa cara seperti Ethernet, WIFI, dan lain sebagainya. Adapun tujuan digunakannya ialah sebagai pengolah data yang diperoleh dari peralatan elektronik dengan melakukan interface antara pengguna dan peralatan tersebut.

Arduino Uno adalah sebuah perangkat board pada mikrokontroller yang berbasis ATmega328 dengan menggunakan kabel USB sebagai alat penghubung ke komputer. Arduino ini memiliki 14 pin input dan output yang mana 6 pin dapat digunakan sebagai output PWM, 6 analog input, crystal osilator $16 \mathrm{MHz}$, koneksi USB, jack power, kepala ICSP, dan tombol reset. Kelebihan yang dimilikinya ialah mempunyai bahasa pemrograman yang tersendiri berupa bahasa $C$. Selain itu untuk board arduino sendiri sudah terdapat loader yang dari USB, sehingga mempermudah dalam membuat program pada mikrokontroler terhadap arduino.

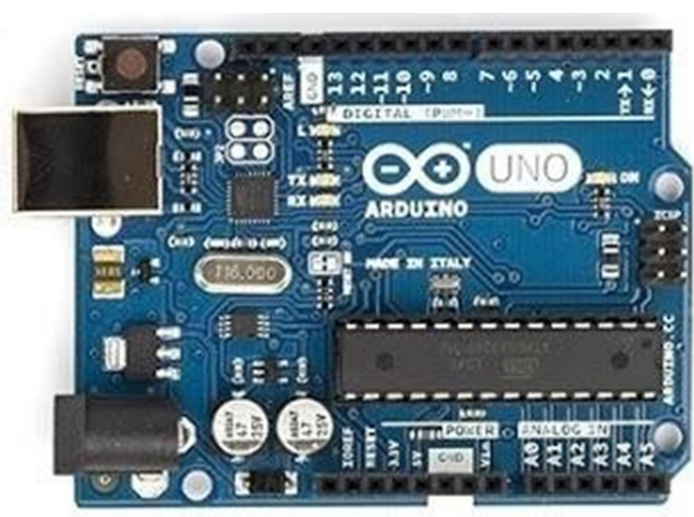

Gambar 2. Arduino Uno Atmega328

Di dalam Arduino Uno juga terdapat beberapa bagian komponen, diantaranya berupa Power USB, Power (Barrel Jack), Voltage Oscillator, Crystal Oscillator, Reset, Pin (3.3, 5, GRN, Vin), Analog pins, Digital pin I/O dan Analog reference.

Relay merupakan alat pengendali perangkat yang memiliki tegangan berupa AC (Lampu) dengan menggunakan asli single secara maksimal 10A/30VDC. Penggunaan relay ini juga dilengkapi dengan optocupler isolation yang berfungsi sebagai alat untuk melindungi perangkat yang apabila arus mengalami pemakaian berlebih. Secara umumnya, beberapa fungsi relay ialah sebagai alat untuk menjalankan Fungsi Logika, Fungsi penundaan durasi waktu, pengendalian sirkuit tegangan tinggi dengan bantuan dari signal tegangan rendah dan sebagai alat untuk melindungi komponen yang apabila terjadi arus hubungan singkat.

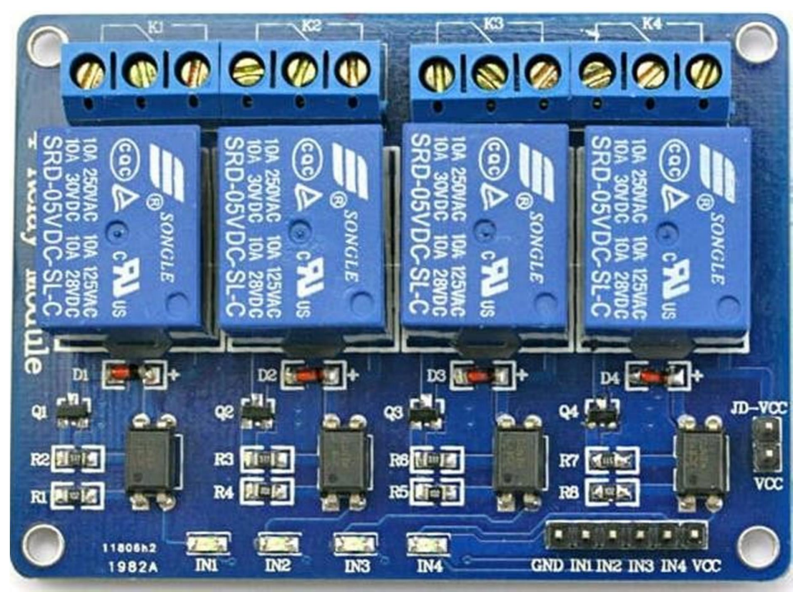

Gambar 3. Relay 
(online), Hal 21 - 31,

Relay juga memiliki spesifikasi, diantaranya berupa input relay $5 \mathrm{vDC}$, maksimum load 250VAC/10A30VDC/10A, dilengkapi dengan optocoupler isolation untuk melindungi board microcontroller dari tegangan $\mathrm{AC}$, memiliki LED indikator, memiliki output keluaran relay maksimum 10A dan dapat menggunakan terminal blok sehingga pemasangan kabel menjadi lebih mudah.

Android adalah sebuah aplikasi sistem operasi pada telepon seluler yang berbasis Linux. Android juga menyediakan platform terbuka bagi para pengembang dalam menciptakan aplikasi mereka sendiri. Kelebihan yang dimiliki android berupa switching dan multitasking yang mendukung aplikasi, kapasitas yang lebih baik dalam beragam widget yang dijanjikan bakal makin memanjakan para penggunanya, peningkatan kemampuan copy-paste dengan mudah, Browser Crome yang lebih cepat, notifikasi yang mudah terdengar, peningkatan Drag and Drop serta Multitouch dengan ukuran layar yang lebih besar dan lain sebagainya. Sedangkan kekurangan yang dimiliki android berupa pemakaian koneksi internet yang boros dibanding ponsel biasa, terdapatnya iklan pada ponsel android sehingga mengganggu pada saat menggunakannya, dan lain sebagainya.

Aplikasi yang akan digunakan pada android yaitu App Invertor. App Invertor adalah sebuah tool dalam membuat aplikasi android yang berbasis visual block programming. Visual block programming adalah dalam drag-drops "blok" yang merupakan simbol- simbol perintah yang berfungsi membuat aplikasi tanpa menuliskan kode program. Didalam App Invertor terdapat tiga opsi untuk melakukan pengujian, yaitu :

1. Membuat aplikasi dengan perangkat Android dengan koneksi Wi-Fi.

2. Membuat aplikasi dengan Emulator pada PC (Personal Komputer).

3. Membuat aplikasi dengan Android dan USB.

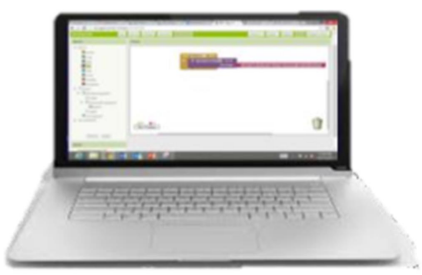

\section{Build your project on} your computer

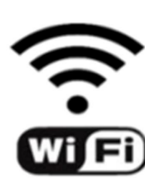

Test it in real-time on your device

Gambar 4. Koneksi Android dengan Wi-Fi

Modul ESP8266 adalah sebuah bentuk dari modul low-cost wifi yang berfungsi sebagai perangkat tambahan mikrokontroler yang terhubung langsung dengan wifi dan dapat membuat koneksi TCP/IP. Kelebihan dari modul ESP8266 ini dapat menjalankan peran sebagai akses poin maupun klien sekaligus dan memiliki kemampuan on-board prosesing dan storage yang dalam diharapkan cocok kepada sensor-sensor yang digunakan sehingga akan mempermudah dalam melakukan integrasi.

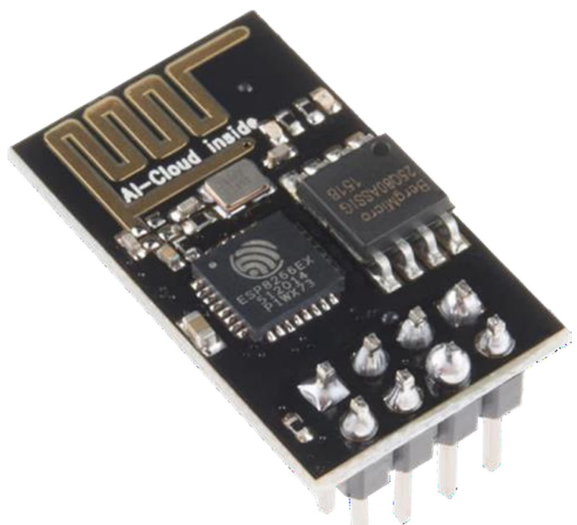

Gambar 5. Modul ESP8266

Copyright $^{\odot} 2021$ TRekRiTel (Teknologi Rekayasa Jaringan Telekomunikasi) : Jurnal Teknik Elektro.

This is an open acces article under the CC-BY-SA lisence (https://creativecommons.org/licenses/by-sa/4.0/). 


\section{METODE}

\section{A. Perancangan Hardware}

Sebelum melakukan perancangan suatu sistem, terlebih dahulu melakukan perancangan blok diagram hingga skema rangkaian. Pembuatan perancangan ini bertujuan agar menghasilkan sistem yang baik. Penggunaan blok diagram merupakan diagram dari sebuah sistem, di mana bagian utama atau fungsi yang diwakili oleh blok dihubungkan dengan garis yang menunjukkan hubungan dari blok tersebut.

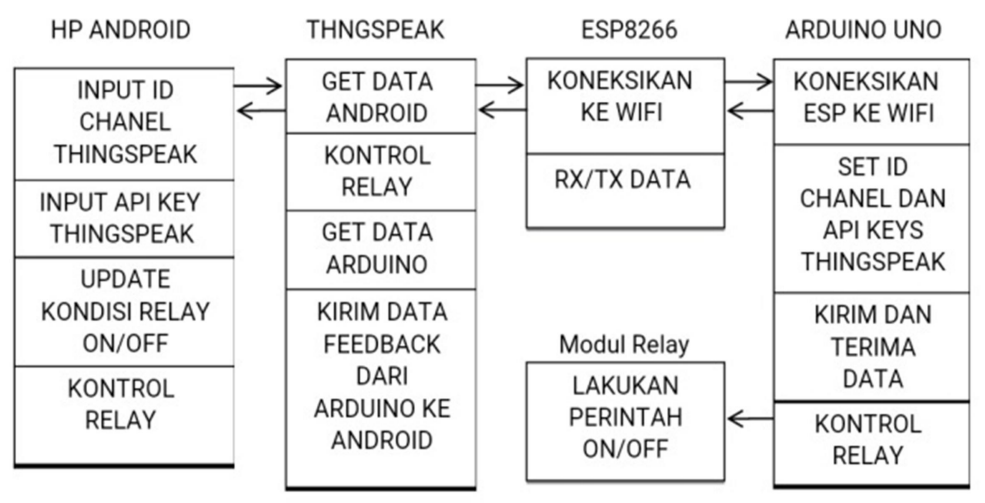

Gambar 6. Blok Diagram

Keterangan :

1. Berdasarkan Hp android yang sebelumnya sudah mendownload aplikasi reconnect, kemudian diatur menggunakan thingspeak dengan memberikan ID chanel dan API Keys yang sudah dibuat dihalaman sebelumnya, sehingga $\mathrm{Hp}$ android dan thingspeak dapat saling berkomunikasi secara benar.

2. Berdasarkan Thingspeak yang telah didapat dari android akan diteruskan ke Arduino Uno dan menerima data kondisi relay secara benar dari Arduino Uno yang akan diteruskan ke android.

3. Berdasarkan ESP8266 akan mendapatkan perintah dari Arduino Uno, agar terkoneksi ke jaringan WiFi dan dilakukan flash terhadap ESP8266 yang sudah ditentukan.

4. Berdasarkan Arduino Uno yang terkoneksi dengan WiFi akan masuk ke halaman Thingspeak untuk menunggu perintah yang akan dikendalikan oleh pengguna menggunakan HP Android.

5. Berdasarkan Relay telah melakukan perintah ON/OFF sesuai yang dikendalikan oleh data yang akan diterima.

\section{B. Perancangan Rangkaian Alat Pengontrol Lampu}

Pada Modul ESP8266 akan dihubungkan ke dalam catu daya 3,3 volt pada Arduino Uno, kemudian dilakukan penyusunan secara paralel pada pin $\mathrm{CH} \_\mathrm{PD}$. Pin $\mathrm{CH} \_\mathrm{PD}$ tersebut akan dihubungkan ke 10 pin Arduino Uno dan pin Rx, sehingga akhirnya dapat dihubungkan ke pin 11 Arduino Uno terakhir.

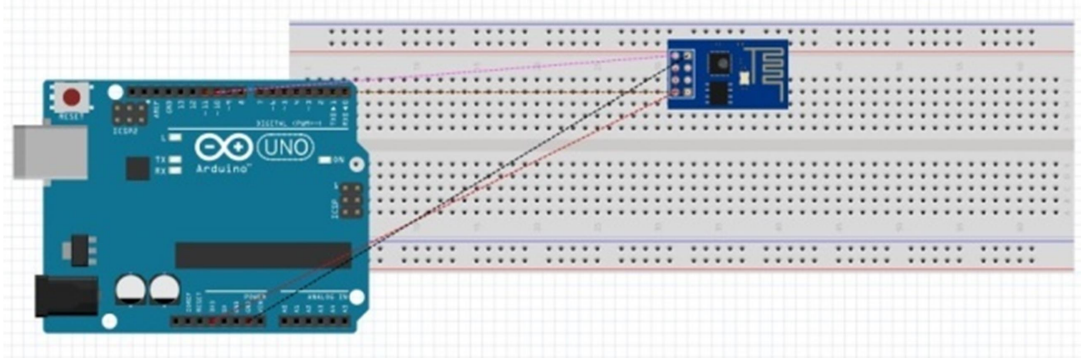

Gambar 7. Rangkaian Modul ESP8266

Pada penggunaan Relay, dimana pada JP2, port 2 kita sebut sebagai IN (input) pada modul relay yang akan menerima masukan dari Arduino Uno. Kemudian IN1 relay dihubungkan pada pin 2 
Arduino Uno, IN2 relay dihubungkan pada pin 3 Arduino Uno, IN3 relay dihubungkan pada pin 4 Arduino Uno dan terakhir IN4 relay dihubungkan pada pin 5 Arduino Uno.

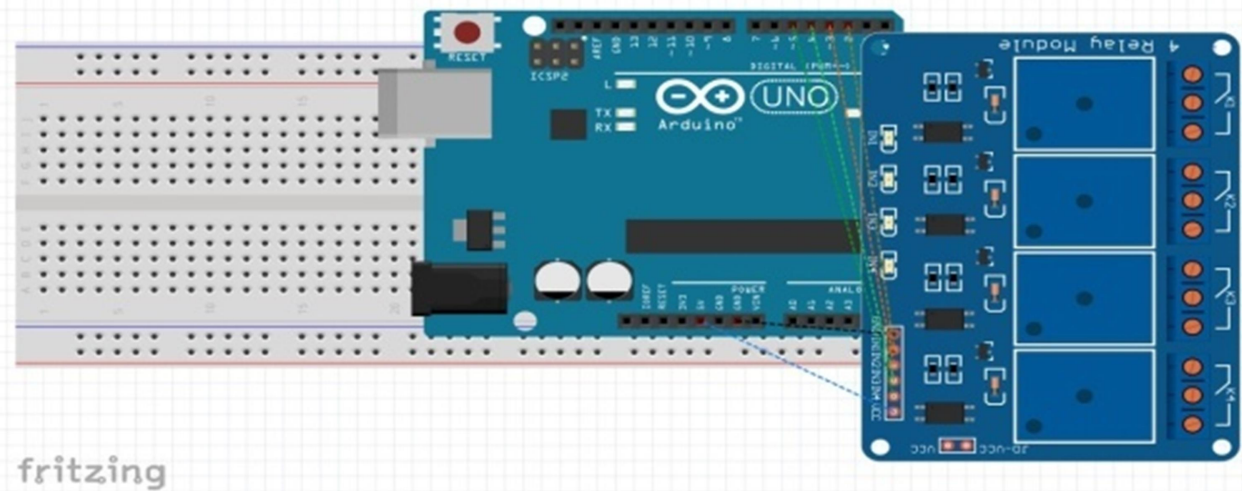

Gambar 8. Rangkaian Relay

Dari Arduino Uno dapat bekerja dengan catu daya 5.5Vdc mendapatkan sumber tegangan dari catu daya itu sendiri. Pin 3.3 volt yang telah terhubung ke VCC dan CH_PD pada modul WiFi ESP8266, lalu Pin 10 dihubungkan ke Tx dan Pin 11 dihubungkan ke Rx modul WiFi ESP8266. Kemudian Pin 2 dihubungkan ke IN1 pada modul relay, Pin 3 dihubungkan ke IN2 pada modul relay, Pin 4 dihubungkan ke IN3 pada modul relay dan Pin 5 dihubungkan ke IN 4 pada modul relay.

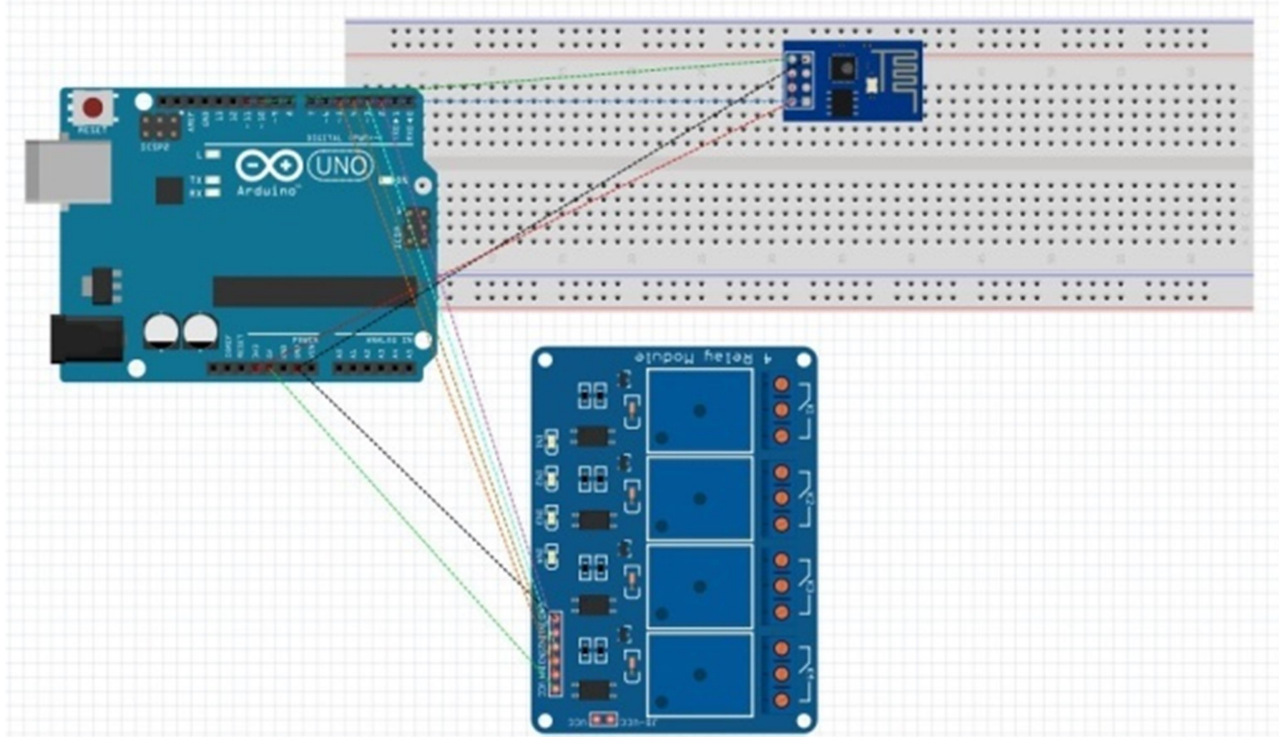

Gambar 9. Rangkaian Arduino

\section{Perancangan Software}

Pada perancangan software ini sudah pasti membuat alur diagram berupa flowchart. Flowchart ini bertujuan untuk menampilkan sebuah diagram dengan simbol-simbol grafis algoritma, serta terdapat simbol dalam bentuk kotak dan lain sebagainya. Untuk penggunaan diagram ini akan menghasilkan ide langkah-langkah untuk penyelesaian masalah dari algoritma tersebut. 


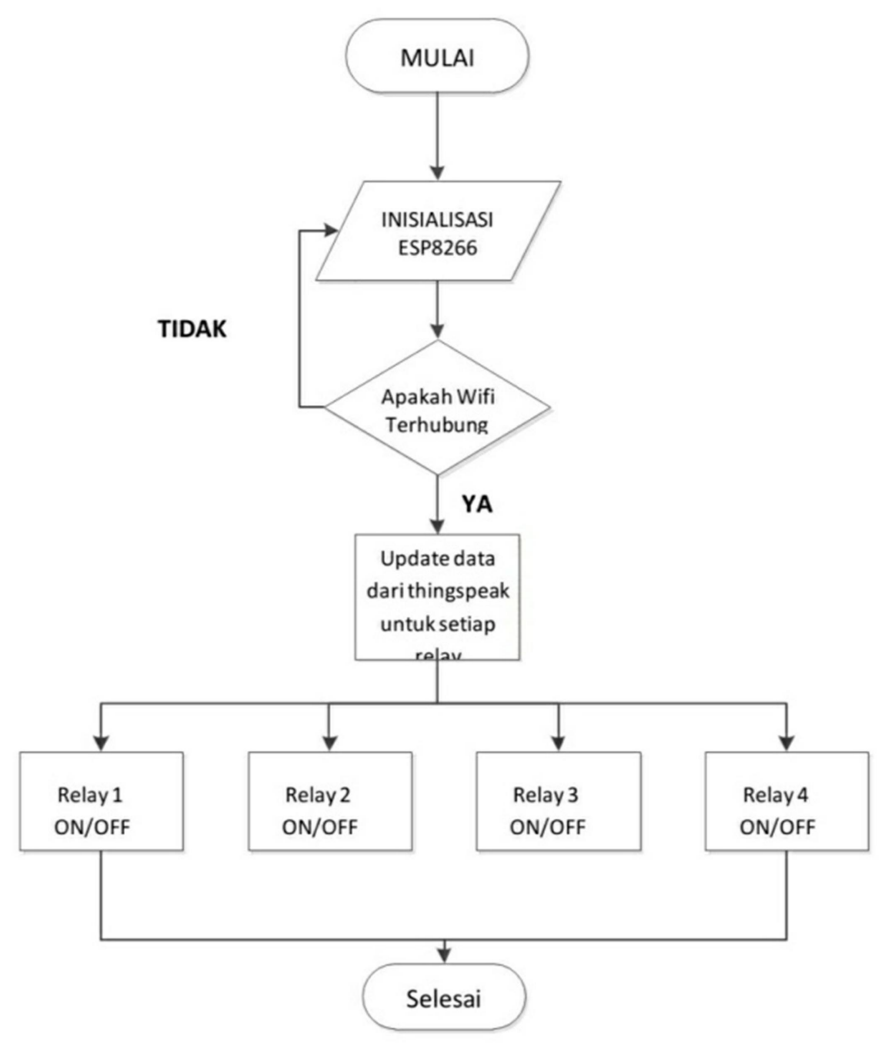

Gambar 10. Flowchart

Berdasarkan dari hasil flowchart diatas, telah menunjukkan langkah alur dari keseluruhan rangkaian tersebut. Pada saat Arduino pertama kali dihubungkan ke laptop maka board Arduino Uno akan melakukan instruksi pada modul ESP8266 yang sebelumnya sudah di flash dan akan terkoneksi pada jaringan WiFi. Kemudian arduino yang sudah terkoneksi dengan internet, maka Arduino Uno akan menghubungkan perangkat ke thingspeak untuk memperbaharui data android secara otomatis.

\section{HASIl DAN PeMbahasan}

\section{A. Hasil Pengukuran Tegangan}

Pertama, pengukuran tegangan Modul Relay ini bertujuan untuk mengetahui besarnya tegangan pada saat akan dihubungkan dengan arduino. Pada perancangan ini memiliki besar tegangan pada modul relay sebesar 5,04 Vdc.

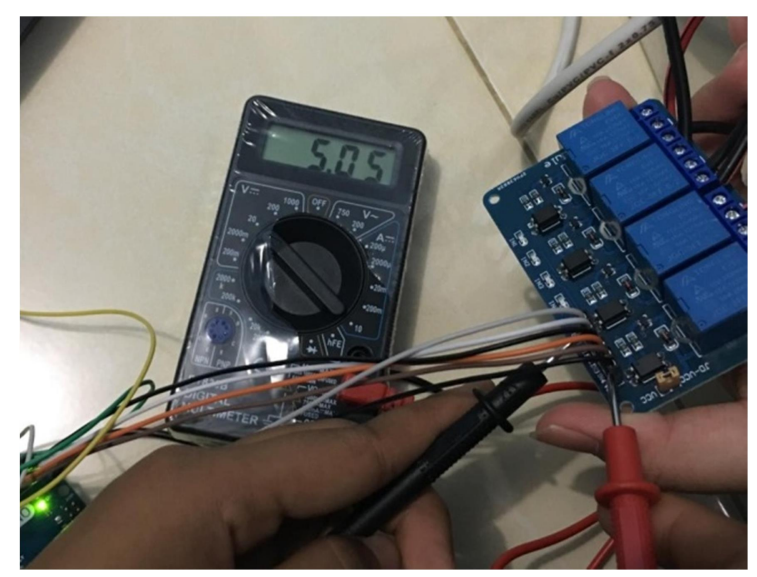

Gambar 11. Pengukuran Tegangan Modul Relay 
(online), Hal 21 - 31,

Kedua, Pengukuran tegangan input modul relay ini bertujuan untuk mengetahui besarnya tegangan yang dibutuhkan pada saat mengaktifkan relay dari setiap channel. Dari perancangan ini relay akan berfungsi apabila sedang dalam kondisi aktif rendah ke setiap masukan pada pin IN1, IN2, IN3 dan IN4. Pengukuran tegangan Modul relay ini bertujuan untuk mengetahui besar tegangan yang ada pada Modul relay pada kondisi OFF. Pada perancangan ini besar tegangan pada modul relay pada kondisi OFF sebesar 5,05 Vdc dan besar tegangan pada modul relay pada kondisi ON sebesar 0,01 Vdc.

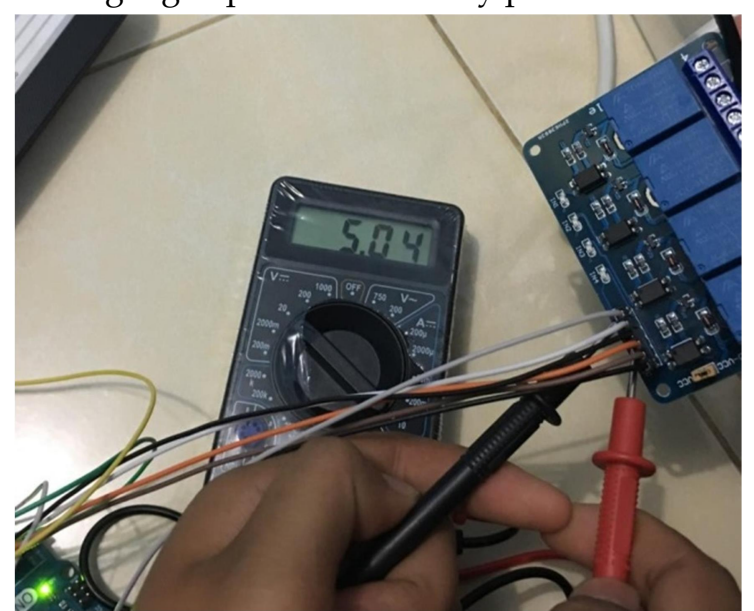

Gambar 12. Pengukuran Tegangan Input Modul Relay OFF

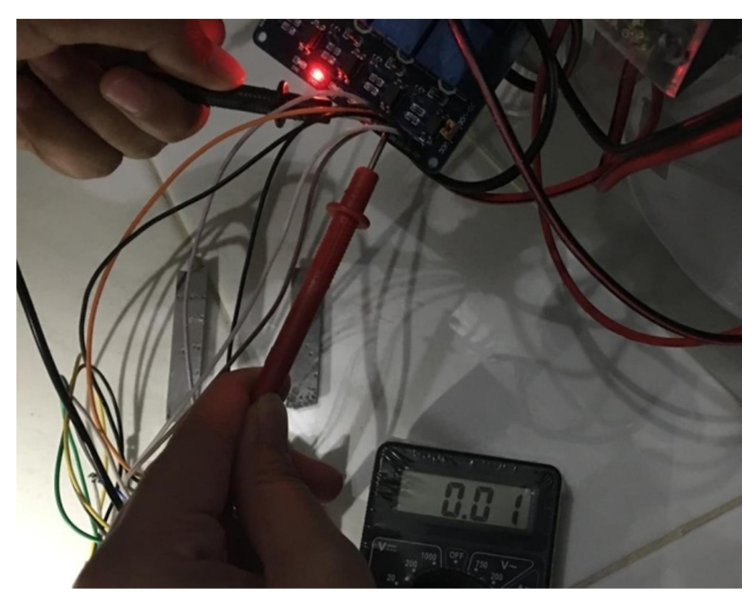

Gambar 13. Pengukuran Tegangan Input Modul Relay ON

Ketiga, pengukuran tegangan pada Modul ESP8266 ini bertujuan untuk mengetahui besarnya tegangan yang ada pada modul ESP8266 dengan saat mengalami kondisi ON sebesar 3,11Vdc.

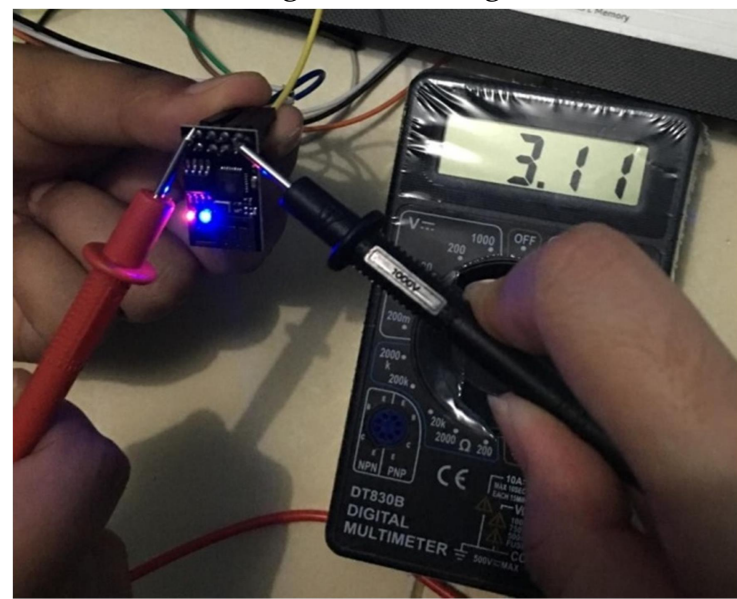

Gambar 14. Pengukuran Tegangan Modul ESP8266 
B. Hasil Pengujian Perancangan dan Pembuatan Alat Pengontrol Lampu menggunakan Internet Of Things (IOT) berbasis Arduino Uno

Tabel 1. Hasil Pengujian Pertama

\begin{tabular}{ccc}
\hline \multirow{2}{*}{ Relay } & \multicolumn{2}{c}{ Waktu (detik) } \\
& Hidup & Mati \\
\hline 2 & 14 & 4 \\
4 & 21 & 20 \\
1 & 12 & 3 \\
3 & 4 & 18 \\
\hline
\end{tabular}

Tabel 2. Hasil Pengujian Kedua

\begin{tabular}{ccc}
\hline \multirow{2}{*}{ Relay } & \multicolumn{2}{c}{ Waktu (detik) } \\
& Hidup & Mati \\
\hline 2 & 60 & 3 \\
4 & 40 & 17 \\
1 & 43 & 54 \\
3 & 27 & 18 \\
\hline
\end{tabular}

Keterangan :

1. Berdasarkan hasil pengujian pertama, pada relay 2 lampu menyala pada detik ke 14, pada relay 4 lampu menyala pada detik ke 21, pada relay 1 lampu menyala pada detik ke 12, pada relay 3 lampu menyala pada detik ke 4 . Pada proses mematikan lampu juga berurut sesuai dengan proses pada saat menghidupkan lampu, yaitu pada relay 2 lampu padam pada detik ke 4 , pada relay 4 lampu padam pada detik ke 20, pada relay 1 lampu padam pada detik ke 3, pada relay 3 lampu padam pada detik ke 18.

2. Berdasarkan hasil pengujian kedua, pada relay 2 lampu menyala pada detik ke 60 , pada relay 4 lampu menyala pada detik ke 40, pada relay 1 lampu menyala pada detik ke 43, pada relay 3 lampu menyala pada detik ke 27. Pada proses mematikan lampu juga berurut sesuai dengan proses pada saat menghidupkan lampu, yaitu pada relay 2 lampu padam pada detik ke 3, pada relay 4 lampu padam pada detik ke 17, pada relay 1 lampu padam pada detik ke 54, pada relay 3 lampu padam pada detik ke 18.

Dengan demikian, melalui hasil pengujian pengontrol lampu yang dilakukan dengan menggunakan aplikasi reconnect, maka dapat diperoleh waktu hidup dan waktu matinya lampu. seperti pada tabel kedua diatas maka dapat dihitung dengan menggunakan alat berupa stopwatch. Terlihat bahwa waktu hidup dan matinya lampu berbeda-beda, hal ini dapat terjadi karena jaringan wifi yang sedang dalam keadaan lambat sehingga setiap lampu memiliki waktu yang berbeda-beda pada proses menyala dan padamnya lampu tersebut.

\section{Tampilan IOT Thingspeak}

Pada saat android mengirimkan data, maka IOT Thingspeak dengan segera akan mengolah data tersebut untuk diterjemahkan serta diteruskan kepada Mikrokontroller Arduino Uno. Setiap data akan mengalami perubahan kondisi relay yang berbeda dan setiap pin modul relay akan direkam setiap hari oleh Thingspeak, karena pada waktu kondisi 1 yang telah menyatakan bahwa relay sedang dalam keadaan $\mathrm{ON}$ dan pada waktu kondisi 0 maka akan menyatakan bahwa relay sedang dalam keadaan OFF. 


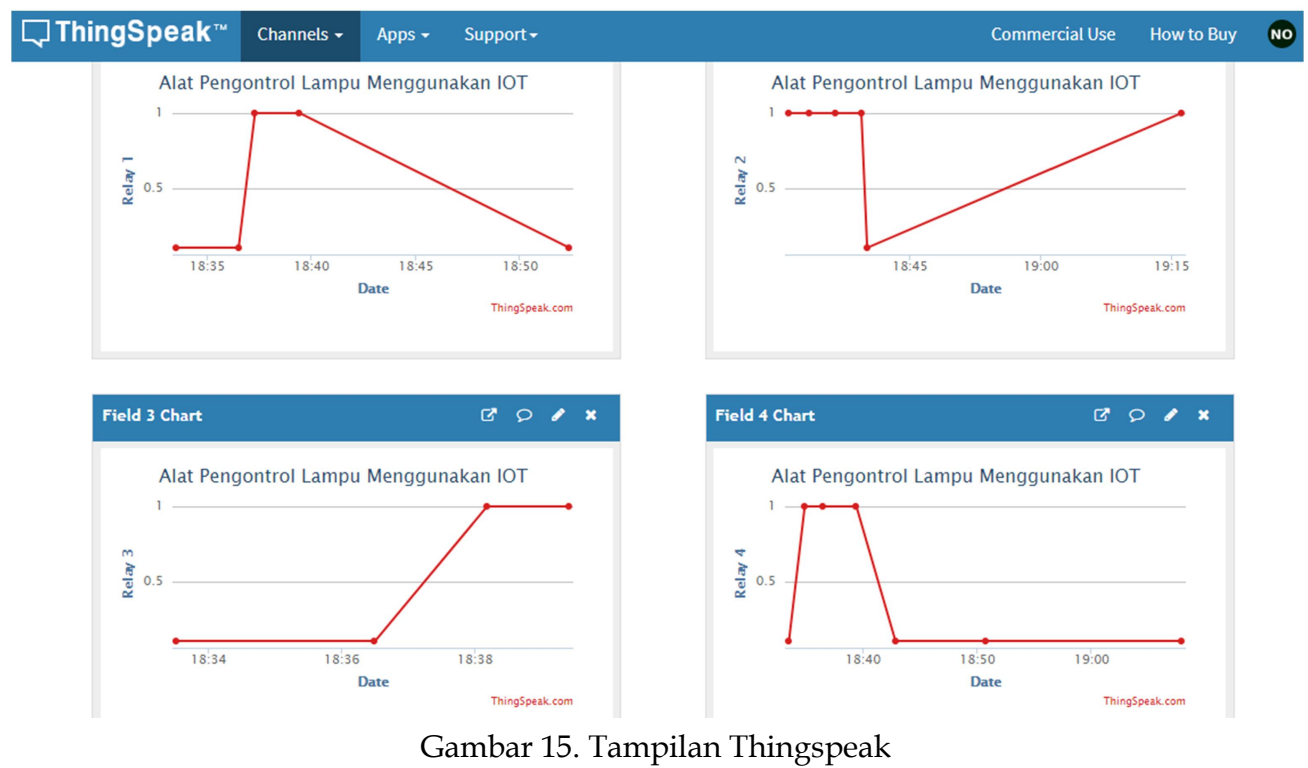

Berdasarkan dari hasil percobaan seperti pada gambar diatas, bahwa tampilan thingspeak pada relay 1 mengalami kondisi pertama yang berada pada keadaan 0 . Hal ini disebabkan karena pada saat wifi terhubung melalui serial monitor yang sedang berjalan, tetapi pada aplikasi reconnect di android ini belum mengirimkan data atau menekan icon relay, sehingga thingspeak akan menampilkan keadaan relay yang sebelumnya dalam kondisi mati atau keadaan 0 . Begitu pula dengan kondisi selanjutnya juga ini dapat mengirimkan data atau dengan menekan icon relay pada aplikasi reconnect, sehingga data dapat terkirim. Begitu pula untuk selanjutnya tetap berada pada keadaan 1 , karena ini disebabkan belum bisa melakukan pengiriman data terbaru atau menekan lama icon relay yang menandakan mematikan lampu pada aplikasi reconnect, sehingga keadaan relay dan lampu tetap seperti sebelumnya hanya menyala. Kondisi selanjutnya berada pada keadaan 0 yang menandakan bahwa baru saja telah mengirimkan data terbaru atau menekan lama icon relay yang menandakan keadaan lampu mengalami mati pada aplikasi reconnect.

Dari hasil relay 2, bahwasanya kondisi pertama berada pada keadaan 1. Hal ini dikarenakan pada saat menekan icon relay di aplikasi reconnect belum melewati loop ke-6, sehingga pada saat setelah melewati loop ke-6 maka relay akan berada pada kondisi sebelumnya. Begitu pula untuk kondisi selanjutnya pada relay 2 tetap pada keadaan 1 yang menandakan bahwa belum terkirimnya data dari aplikasi reconnect, kondisi 1 (satu) berlangsung selama 4 kali sehingga yang menandakan telah melewati loop ke-6 selama 4 kali, kondisi selanjutnya yaitu keadaan 0 menandakan telah mengirimkan data dari reconnect. Kemudian pada thingspeak akan berubah, sehingga dapat mengirimkan data kembali untuk menyalakan lampu, maka dari itu relay tetap berada pada kondisi kembali dengan keaadaan 1.

Selanutnya pada relay 3 kondisi pertama sedang berada pada keadaan 0 . Hal ini disebabkan ketika wifi telah terhubung lalu serial monitor akan berjalan dan melakukan looping, namun pada aplikasi reconnect di android ini belum bisa mengirimkan data atau menekan icon relay untuk relay 3 , sehingga pada thingspeak akan menampilkan keadaan relay dari sebelumnya dengan kondisi mati atau keadaan 0 . Begitu pula pada kondisi selanjutnya, kemudian setelah ini mengirimkan data atau menekan icon relay pada aplikasi reconnect data akan terkirim dan tampilan thingspeak akan berubah menjadi keadaan 1 , sehingga lampu tersebut menandakan sedang menyala. Kemudian untuk kondisi selanjutnya tetap berada pada keadaan 1 . Hal ini dikarenakan belum bisa mengirimkan data terbaru atau menekan lama pada icon relay dengan menandakan lampu sedang mati pada aplikasi reconnect, sehingga keadaan relay dan lampu tetap seperti sebelumnya dalam kondisi menyala.

Terakhir untuk relay 4 dengan kondisi pertama berada pada keadaan 0. Hal ini disebabkan ketika wifi telah terhubung lalu serial monitor sedang berjalan dan melakukan looping, namun pada aplikasi reconnect di android ini belum bisa mengirimkan data atau menekan icon relay untuk relay 4 . Sehingga pada thingspeak akan menampilkan keadaan relay sebelumnya dengan kondisi mati atau keadaan 0 . Selanjutnya untuk kondisi yang sedang melakukan pengiriman data atau menekan icon relay pada aplikasi reconnect, data akan terkirim pada tampilan thingspeak juga akan mengalami perubahan menjadi keadaan 1 dan menandakan lampu sedang menyala. Begitu pula untuk kondisi selanjutnya 
tetap berada pada keadaan 1, hal ini dikarenakan ini belum bisa mengirimkan data terbaru atau menekan lama icon relay yang menandakan bahwasanya lampu sedang dalam keadaan mati pada aplikasi reconnect. Sehingga keadaan relay dan lampu tetap seperti sebelumnya mengalami keadaan menyala. Dan begitu pula ini dapat mengirimkan data atau menekan lama icon relay pada aplikasi reconnect. Begitupun juga untuk mematikan lampu, maka data akan melakukan pengiriman dahulu sehingga tampilan thingspeak mengalami kondisi dengan bahwasanya menandakan lampu sedang dalam keadaan mati.

\section{KeSIMPULAN}

Berdasarkan hasil dan pembahasan dengan melakukan perancangan dan pengujian tersebut, sehingga dapat disimpulkan sebagaimana mestinya yang telah ditetapkan dari hasil uji coba sebelumnya. Melalui hal ini bahwasanya, pada saat melakukan pengujian dengan melakukan kontrol yang menggunakan Arduino Uno terdapat jeda waktu paling lama pengujian selama 1 menit. Selanjutnya akan mengalami bentuk respon yang lama karena disebabkan oleh paket data internet dan trafic server yang sangat padat. Kemudian untuk program Arduino Uno telah diberikan jeda waktu selama 5 detik untuk perpindahan perintah serial dari satu relay ke relay yang lain. Dan terakhir waktu jeda yang diberikan untuk mencegah interferensi atau tabrakan dalam komunikasi data tersebut.

\section{DAFTAR PUSTAKA}

[1] Santoso, Hari. 2015. Panduan praktis Arduino untuk pemula. www.elangsakti.com :Malang

[2] Meri. Wardana, 2011, Prinsip kerja relay. www.meriwardanaku.com

[3] Wasista, Sigit, Setiawardhana, Delima Ayu Saraswati, dan Eko Susanto, 2019. Aplikasi Internet of Things (IOT) dengan Arduino dan Android. Yogyakarta :DEEPUBLISH

[4] Ismail, R. 2017. Pemanfaatan sistem android sebagai pengendali lampu ruangan berbasis mikrokontroler arduino. Teknik Elektro.Kupang

[5] https://www.researchgate.net/publication/337933126_Kontrol_Lampu_Otom atis_Berbasis_Arduino_Dengan_Smartphone Diakses pada tanggal 21 April 2020, Pukul 20.32WIB

[6] https://www.researchgate.net/publication/332192788_Penerapan_Internet_Of Things_IoT_Untuk_Kontrol_Lampu_Menggunakan_Arduino_Berbasis_Web Diakses pada tanggal 21 April 2020, Pukul 21.25 WIB

[7] https://media.neliti.com/media/publications/236219-pemanfaatan-internet-of- things-padakend-9849b1dd.pdfDiaksespadatanggal22April2020,Pukul 14.20 WIB

[8] https://www.mitra-led.com/news/10/Definisi-Lampu-Jenis-Jenis-dan- FungsinyaDiakses pada tanggal 23 April 2020, Pukul 15.30WIB

[9] https://www.dewaweb.com/blog/internet-of-things/ Diakses pada tanggal 23 April 2020, Pukul 15.35WIB

[10] https://jurnal.umj.ac.id/index.php/semnastek/article/view/521 Diakses pada tanggal 16 Agustus 2020, Pukul 20.52WIB 